\title{
On-line Gas Chromatography of Mo, W and U (Oxy)chlorides*
}

\author{
By M. Gärtner ${ }^{1}$, M. Boettger ${ }^{4}$, B. Eichler ${ }^{2}$, H. W. Gäggeler ${ }^{1,2}$, M. Grantz ${ }^{4}$, S. Hübener ${ }^{4}$, D. T. Jost ${ }^{2}$, \\ D. Piguet $^{2}$, R. Dressler ${ }^{3}$, A. Türler ${ }^{2}$ and A. B. Yakushev ${ }^{3}$ \\ 1 Labor für Radio- und Umweltchemie, Universität Bern, 3000 Bern, Switzerland \\ ${ }^{2}$ Labor für Radio- und Umweltchemie, Paul-Scherrer-Institut, 5232 Villigen, Switzerland \\ ${ }^{3}$ Flerov Laboratory for Nuclear Reactions, Dubna, 141980 Russia \\ 4 Institut für Radiochemie, Forschungszentrum Rossendorf, D-01314 Dresden, Germany
}

(Received May 20, 1997; accepted in revised form September 8, 1997)

On-line gas chromatography / Group 6 Elements / Uranium / Chlorides / Oxychlorides

\begin{abstract}
Summary
Group 6 elements are known to form volatile chlorides and oxychlorides. These compounds are therefore suited for separations with the On-Line Gaschemistry Apparatus OLGA, a device which is able to isolate volatile species at a maximum temperature of $500^{\circ} \mathrm{C}$. OLGA has previously been used to study the group 4 and 5 halides. In preparation of experiments with element $106(\mathrm{Sg}=$ seaborgium $)$, a member of group 6, first, a literature survey on the thermochemical properties of chlorides and oxychlorides of Mo and W as well as of the pseudo-group 6 element $U$ was made. Second, OLGA experiments were performed with short-lived isotopes of $\mathrm{Mo}, \mathrm{W}$ and $\mathrm{U}$, using $\mathrm{Cl}_{2}$, saturated with $\mathrm{SOCl}_{2}$ for chlorination, and different partial pressures of $\mathrm{O}_{2}$. Under such conditions, these elements formed species, which were volatile in quartz chromatography columns at temperatures $\leq 250^{\circ} \mathrm{C}$.
\end{abstract}

\section{Introduction}

Until recently, the heaviest element whose chemical properties have been studied, was element $105(\mathrm{Db}=$ dubnium** $[1,2]$, a group 5 element. Db showed partly surprising properties: in aqueous phase investigations, it resembled much more $\mathrm{Nb}$ and/or $\mathrm{Pa}$ and not $\mathrm{Ta}$ [3]. In gas phase studies, $\mathrm{Db}$ was found to behave differently from $\mathrm{Nb}$ and $\mathrm{Ta}$ [4]. It remains open, if these observations are a result of so-called relativistic effects, which are predicted to influence the chemical properties of heaviest elements [5].

In 1994 the discovery of ${ }^{265} \mathrm{Sg}$ and ${ }^{266} \mathrm{Sg}$ [6] provided a major opportunity to extend chemical studies to element $106(\mathrm{Sg}=$ Seaborgium $)$. From the measured $\alpha$-decay energies rather long half-lives of $2-30 \mathrm{~s}$ for ${ }^{265} \mathrm{Sg}$ and $10-30 \mathrm{~s}$ for ${ }^{266} \mathrm{Sg}$ were predicted. All previously known $\mathrm{Sg}$ isotopes had half-lives $<1 \mathrm{~s}$. Seaborgium is a member of group 6 of the Periodic Table. Hence, Mo and $\mathrm{W}$ are its lighter homologues. Thermodynamic predictions indicate that Sg should

\footnotetext{
* Presented at the 4th International Conference on Nuclear and Radiochemistry, St. Malo, France, September 1996.

** In this work, the element names accepted recently by IUPAC are used.
}

form stable, highly volatile chloride or oxychloride compounds as do the other group 6 elements $[7,8]$. A first attempt to study the volatility of seaborgium oxychloride, using the thermochromatography technique, has been performed recently with the shortlived isotope ${ }^{263} \mathrm{Sg}\left(T_{1 / 2}=0.9 \mathrm{~s}\right)[9,10,11]$. However, since the detection of ${ }^{263} \mathrm{Sg}$ based on spontaneous-fission track counting in the chromatography column after the experiment - a decay mode which is not specific to a given nuclide - the result of this study failed to unambiguously prove that the species isolated is indeed from an isotope of $\mathrm{Sg}$.

In this work, an evaluation of thermochemical data of the chlorides and oxychlorides of $\mathrm{W}, \mathrm{Mo}$ and $\mathrm{U}$ is made. This basis is then used to propose a suitable gas chemical separation scheme for isolation of these elements with the On-Line Gas chemistry Apparatus OLGA [12]. Finally, experiments to separate shortlived isotopes of Mo, $\mathrm{W}$ and $\mathrm{U}$ using an oxygen containing chlorinating agent are described.

\section{Stability and volatility of group 6 chlorides and oxychlorides}

There exist a large number of chloride and oxychloride compounds of group 6 elements. However, application of thermochemical properties - which are valid for macroamounts - to single atoms or molecules is not a trivial matter. For example, the position of a chemical equilibrium must be translated to a probability that a single atom or molecule reaches the same chemical state as in the macroscopic system. This is easiest to achieve if the $\mathrm{K}$ value of the equilibrium is largely different form 1. In addition, one also has to keep in mind, that the formation of homobinuclear species or even polymers is highly unlikely.

\subsection{Stability of chlorides and oxychlorides}

The binding energies within a compound are a measure of the stability of a molecule in a given oxidation state. The binding energy of a chlorine atom in pure gaseous chlorides is characterized by the dissociation enthalpy $\left(\Delta H_{\text {diss }}^{\mathrm{o}}\right)$ in the reaction: 


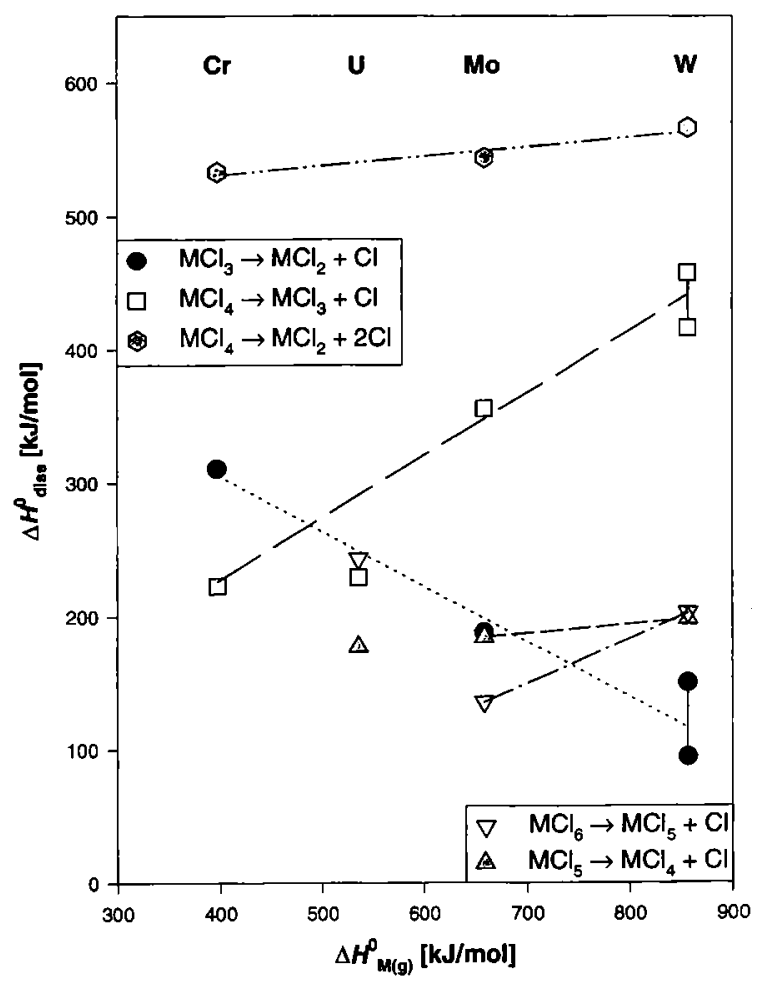

Fig. 1. Molar standard enthalpies of dissociation $\Delta H_{\text {diss }}^{\mathrm{o}}\left(\mathrm{MCl}_{\mathrm{x}}\right)$ with $\mathrm{M}=\mathrm{Cr}, \mathrm{Mo}, \mathrm{W}, \mathrm{U}$ and $\mathrm{x}=3,4,5,6$ as a function of the standard enthalpy of the gaseous metal $\Delta H_{\mathrm{M}(\mathrm{g})}^{\mathrm{o}}$. The tendencies within the group 6 elements are symbolized with dotted, dasheddotted or dashed regression lines, respectively. Two extrapolated values for $\mathrm{WCl}_{3}$ and $\mathrm{WCl}_{4}$ are given (see text). For the reaction $\mathrm{MCl}_{4} \rightarrow \mathrm{MCl}_{2}+2 \mathrm{Cl} \Delta \mathrm{H}_{\mathrm{diss}}^{\mathrm{o}}\left(\mathrm{MCl}_{\mathrm{x}}\right)$ includes the value of two $\mathrm{Cl}$ atoms.

$$
\mathrm{MCl}_{\mathrm{x}(\mathrm{g})} \leftrightarrow \mathrm{MCl}_{\mathrm{x}-1(\mathrm{~g})}+\mathrm{Cl}_{(\mathrm{g})}
$$

The dependence of $\Delta H_{\text {diss }}^{0}\left(\mathrm{MCl}_{\mathrm{x}}\right)$ with $\mathrm{M}=\mathrm{Cr}$, Mo, $\mathrm{W}, \mathrm{U}$ and $\mathrm{x}=3,4,5,6$ on the standard enthalpy of the gaseous metal $\left(\Delta H_{\mathrm{M}(\mathrm{g})}^{\mathrm{o}}\right)[13,14]$ is shown in Fig. 1 . The highest known pure chloride of $\mathrm{Cr}$ is $\mathrm{CrCl}_{4(\mathrm{~g})}$ [15], $\mathrm{MoCl}_{6}$ is unstable and exists probably only in the gas phase in the presence of $\mathrm{Cl}_{2}$ [15], $\mathrm{WCl}_{6}$ is stable compared to the other hexachlorides of group 6 . The binding energy of the $\mathrm{M}-\mathrm{Cl}$ bond changes strongly with oxidation state. Since there is no data available for gaseous $\mathrm{WCl}_{3}, \Delta H_{\mathrm{diss}}^{\mathrm{O}}\left(\mathrm{WCl}_{3}\right)$ was estimated in two different ways. First, the formation enthalpy $\left(\Delta H_{\mathrm{form}}^{0}\right)$ of $\mathrm{WCl}_{3}$ was extrapolated from a correlation between $\Delta H_{\mathrm{M}(\mathrm{g})}^{\mathrm{o}}$ and $\Delta H_{\text {form }}^{\mathrm{o}}\left(\mathrm{MCl}_{3}\right)(\mathrm{M}=\mathrm{Cr}, \mathrm{Mo})$. Second, $\Delta H_{\text {diss }}^{\mathrm{o}}\left(\mathrm{WCl}_{3}\right)$ was estimated by extrapolating $\Delta H_{\mathrm{diss}}^{\mathrm{o}}\left(\mathrm{MCl}_{3}\right)(\mathrm{M}=\mathrm{Cr}, \mathrm{Mo})$ as a function of $\Delta H_{\mathrm{M}(\mathrm{g})}^{\mathrm{o}}$. The results of both procedures are shown in Fig. 1. The binding energy of the last $\mathrm{Cl}$ atom in gaseous $\mathrm{MCl}_{3}$ decreases with increasing $\mathrm{Z}$, which is a sign of increasing promotion energies and disadvantageous binding geometry. In macroscopic systems, the pentachlorides are stabilized by the formation of dimers, which is not possible in carrier-free systems. However, the formation of heterobinuclear species with possible contaminants such as $\mathrm{FeCl}_{3}$ and $\mathrm{AlCl}_{3}$ has to be considered.

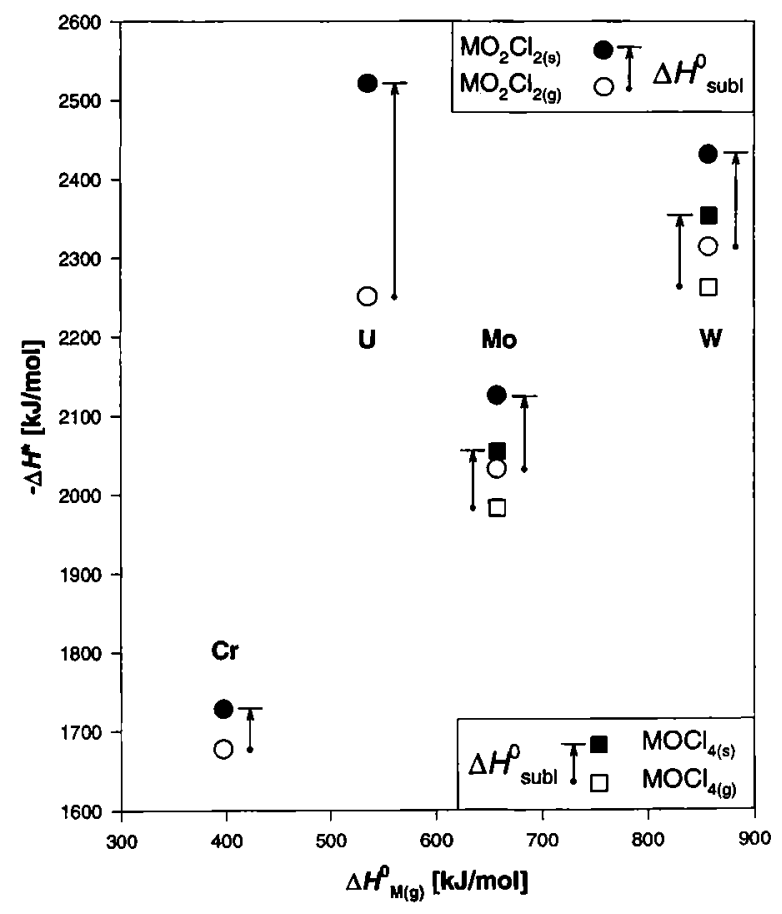

Fig. 2. Atomic formation enthalpies of the gaseous or solid species $\Delta H^{*}$ from single atoms as a function of the standard enthalpy of the gaseous metal $\Delta H_{\mathrm{M(g)}}^{\mathrm{o}}: \Delta H^{*}-$ values for solid $\left(\Delta H_{(\mathrm{s})}^{*}\right)$ and gaseous $\left(\Delta H_{(\mathrm{g})}^{*}\right)$ dioxydichlorides and oxytetrachlorides of group 6 elements and uranium. The standard sublimation enthalpies $\Delta H_{\text {sub }}^{0}$ are indicated by arrows.

In contrast to $\mathrm{W}, \mathrm{U}$ exhibits fundamental differences. While the binding energies of the last $\mathrm{Cl}$ atoms in $\mathrm{UCl}_{4}$ and $\mathrm{UCl}_{5}$ are approaching the tendencies observed in group 6, the binding energy of the 6th $\mathrm{Cl}$ atom in $\mathrm{UCl}_{6}$ is considerably higher than that in $\mathrm{MoCl}_{6}$ or $\mathrm{WCl}_{6}$.

The complete break-up of a gaseous molecule into its constituting atoms in the gas phase corresponds to the atomic formation enthalpy of the gaseous $\left(\Delta H_{(\mathrm{g})}^{*}\right)$ or solid $\left(\Delta H_{(\mathrm{s})}^{*}\right)$ species from single atoms $\Delta H^{*}$. While $\Delta H_{\text {diss }}^{\mathrm{o}}$ yields information about the relative stability of oxidation states, $\Delta H^{*}$ characterizes the stability of a molecule. In Fig. $2, \Delta H_{(\mathrm{g})}^{*}$ and $\Delta H_{(\mathrm{s})}^{*}$ values for dioxydichlorides and oxytetrachlorides of group 6 elements and of uranium are shown as a function of $\Delta H_{\mathrm{Mg})}^{\mathrm{o}}[13,16-19]$. The difference between $\Delta H_{(\mathrm{s})}^{*}$ and $\Delta H_{(\mathrm{g})}^{*}$ is the standard sublimation enthalpy $\left(\Delta H_{\mathrm{subl}}^{\mathrm{o}}\right), \Delta H_{\mathrm{M}(\mathrm{g})}^{\mathrm{o}}$ increases with $\mathrm{Z}$ within the group 6 while $\mathrm{U}$ does not follow this trend. The stability of a molecular species increases with $\Delta H_{\mathrm{M}(\mathrm{g})}^{0}$, if the linear correlations $\Delta H^{*}$ versus $\Delta H_{\mathrm{Mg})}^{0}$ for the gaseous and solid compounds have slopes $>1$. This is caused by the fact, that $\Delta H^{*}$ is not an independent variable, but is the sum of $\Delta H_{\mathrm{M}(\mathrm{g})}^{\mathrm{o}}, \Delta H_{\mathrm{form}}^{\mathrm{o}}, \Delta H_{\mathrm{Cl}(\mathrm{g})}^{\mathrm{o}}$ and $\Delta H_{\mathrm{O}(\mathrm{g})}^{\mathrm{o}}$. As shown in Fig. 2, this condition (slope $>1$ ), is fulfilled for the dioxydichlorides. In addition, the stability of the solid compounds increases faster than that of gaseous compounds. Therefore, $\Delta H_{\text {sub }}^{0}$ increases systematically in the order (see Table 1): 
Table 1. Thermochemical properties of Mo-, W- and U-compounds. The compilation includes measured and evaluated data from the literature: melting point (m.p.), boiling point (b.p.), decomposition, standard formation enthalpy $\left(\Delta \mathrm{H}_{\text {form }}^{9}\right)$ and standard entropy $\left(\mathrm{S}_{\text {(sate) }}^{0}\right)$. Also listed are adsorption enthalpies $\Delta \mathrm{H}_{\text {ads }}$ for trace amounts on quartz surfaces deduced from the $\Delta \mathrm{H}_{\text {subl }}^{0}(298)$ values using Eq. (17) as well as mean values for $\Delta H_{\text {subl }}^{0}(298), \Delta S_{\text {subl }}^{o}(298)$ and $\Delta H_{\text {ads }}$ which are mentioned in the text

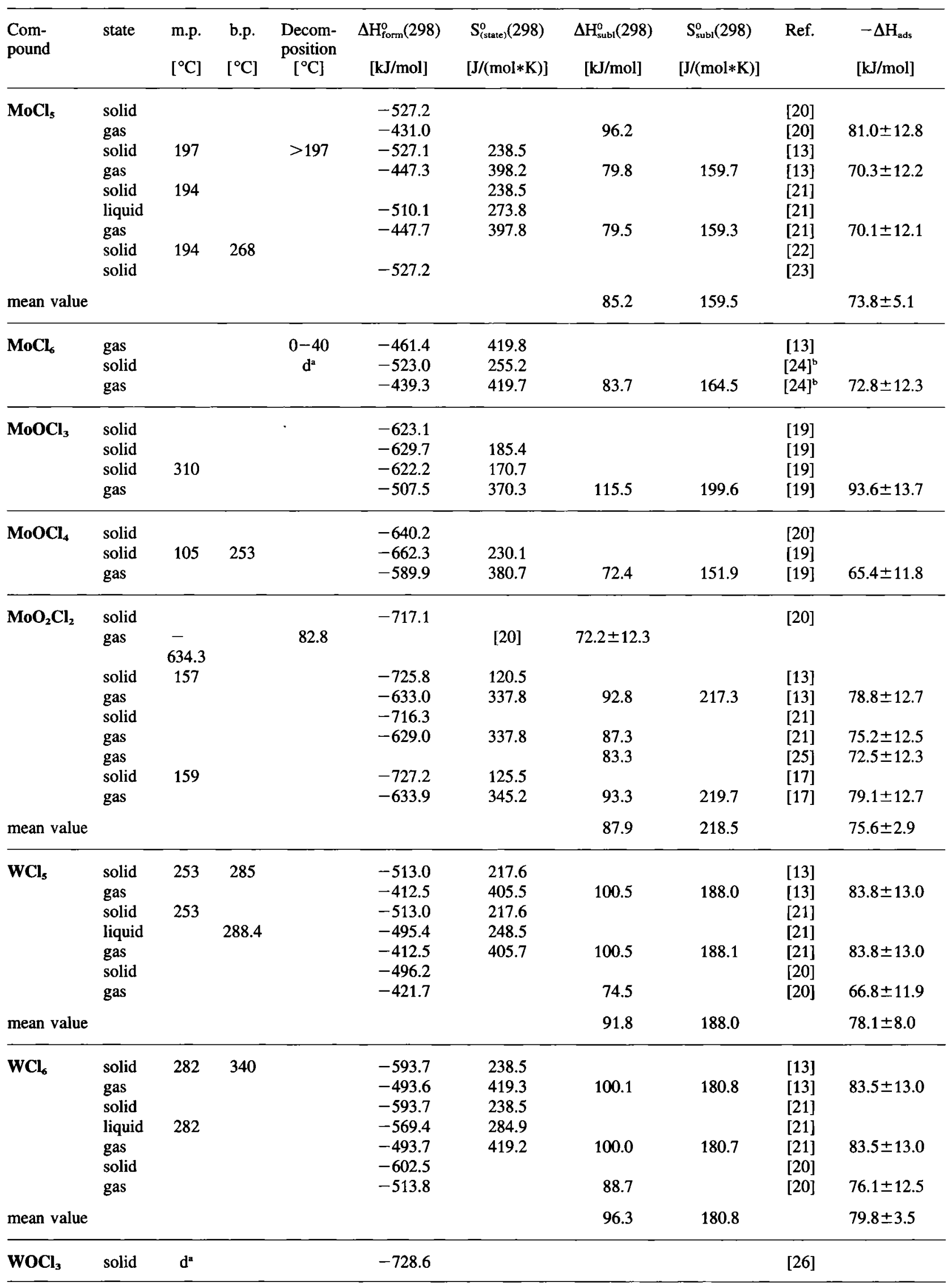


Table 1. Continuation

\begin{tabular}{|c|c|c|c|c|c|c|c|c|c|c|}
\hline $\begin{array}{l}\text { Com- } \\
\text { pound }\end{array}$ & state & $\begin{array}{l}\text { m.p. } \\
{\left[{ }^{\circ} \mathrm{C}\right]}\end{array}$ & $\begin{array}{l}\text { b.p. } \\
{\left[{ }^{\circ} \mathrm{C}\right]}\end{array}$ & $\begin{array}{c}\text { Decom- } \\
\text { position } \\
{\left[{ }^{\circ} \mathrm{C}\right]}\end{array}$ & $\begin{array}{c}\Delta \mathrm{H}_{\text {form }}^{\mathrm{o}}(298) \\
{[\mathrm{kJ} / \mathrm{mol}]}\end{array}$ & $\begin{array}{l}\mathrm{S}_{\text {(state) }}^{0}(298) \\
{[\mathrm{J} /(\mathrm{mol} * \mathrm{~K})]}\end{array}$ & $\begin{array}{c}\Delta \mathrm{H}_{\mathrm{subl}}^{\mathrm{o}}(298) \\
{[\mathrm{kJ} / \mathrm{mol}]}\end{array}$ & $\begin{array}{c}\mathrm{S}_{\mathrm{subl}}^{\mathrm{o}}(298) \\
{[\mathrm{J} /(\mathrm{mol} * \mathrm{~K})]}\end{array}$ & Ref. & $\begin{array}{l}-\Delta \mathrm{H}_{\mathrm{ads}} \\
{[\mathrm{kJ} / \mathrm{mol}]}\end{array}$ \\
\hline WOCl $_{4}$ & $\begin{array}{l}\text { solid } \\
\text { gas } \\
\text { solid } \\
\text { liquid } \\
\text { gas } \\
\text { solid } \\
\text { gas } \\
\text { solid } \\
\text { gas }\end{array}$ & $\begin{array}{l}211 \\
211\end{array}$ & $\begin{array}{l}220 \\
220\end{array}$ & & $\begin{array}{l}-671.1 \\
-573.4 \\
-671.1 \\
-630.6 \\
-573.5 \\
-676.6 \\
-586.0 \\
-761.5 \\
-670.3\end{array}$ & $\begin{array}{l}172.8 \\
377.1 \\
172.8 \\
253.6 \\
377.1 \\
\\
\\
234.3\end{array}$ & $\begin{array}{l}97.7 \\
97.6 \\
90.6 \\
91.2\end{array}$ & 204.3 & $\begin{array}{l}{[13]} \\
{[13]} \\
{[21]} \\
{[21]} \\
{[21]} \\
{[20]} \\
{[20]} \\
{[18]} \\
{[18]}\end{array}$ & $\begin{array}{l}81.9 \pm 12.9 \\
77.3 \pm 12.6 \\
77.7 \pm 12.6\end{array}$ \\
\hline mean value & & & & & & & 94.3 & 198.0 & & $79.8 \pm 2.2$ \\
\hline $\mathrm{WO}_{2} \mathrm{Cl}_{2}$ & $\begin{array}{l}\text { solid } \\
\text { gas } \\
\text { solid } \\
\text { gas } \\
\text { solid } \\
\text { gas } \\
\text { solid } \\
\text { gas }\end{array}$ & & & $\begin{array}{l}369 \\
369\end{array}$ & $\begin{array}{l}-780.3 \\
-671.5 \\
-780.3 \\
-671.5 \\
-783.2 \\
-686.0 \\
-832.6 \\
-715.5\end{array}$ & $\begin{array}{l}200.8 \\
353.9 \\
200.8 \\
353.9 \\
\\
142.3\end{array}$ & $\begin{array}{r}108.8 \\
108.8 \\
97.2 \\
117.6\end{array}$ & $\begin{array}{l}153.1 \\
153.1\end{array}$ & $\begin{array}{l}{[13]} \\
{[13]} \\
{[21]} \\
{[21]} \\
{[20]} \\
{[20]} \\
{[18]} \\
{[18]}\end{array}$ & $\begin{array}{l}89.3 \pm 13.4 \\
89.3 \pm 13.4 \\
81.7 \pm 12.9 \\
95.0 \pm 13.7\end{array}$ \\
\hline mean value & & & & & & & 108.1 & 161.3 & & $88.8 \pm 4.7$ \\
\hline $\mathbf{U C l}_{5}$ & $\begin{array}{l}\text { solid } \\
\text { solid } \\
\text { solid }\end{array}$ & & & 94 & $\begin{array}{l}-1094.1 \\
-1036.4 \\
-1041.5\end{array}$ & $\begin{array}{l}242.7 \\
246.9\end{array}$ & & & $\begin{array}{l}{[27]} \\
{[28]} \\
{[13]}\end{array}$ & \\
\hline $\mathbf{U C l}_{6}$ & $\begin{array}{l}\text { solid } \\
\text { gas } \\
\text { solid }\end{array}$ & 178 & & 95 & $\begin{array}{r}-1068.2 \\
-987.8 \\
-1132.6\end{array}$ & $\begin{array}{l}285.8 \\
432.7 \\
285.8\end{array}$ & 80.3 & 147.0 & $\begin{array}{l}{[13]} \\
{[13]} \\
{[27]}\end{array}$ & $70.6 \pm 12.2$ \\
\hline $\mathrm{UOCl}_{3}$ & solid & & & & -1151.6 & 170.7 & & & [13] & \\
\hline $\mathrm{UO}_{2} \mathrm{Cl}_{2}$ & $\begin{array}{l}\text { solid } \\
\text { gas } \\
\text { solid }\end{array}$ & 577 & 1253 & & $\begin{array}{r}-1243.5 \\
-973.9 \\
-1243.5\end{array}$ & $\begin{array}{l}150.6 \\
372.5\end{array}$ & 269.6 & 221.9 & $\begin{array}{l}{[13]} \\
{[13]} \\
{[29]}\end{array}$ & $194.6 \pm 20.1$ \\
\hline
\end{tabular}

a d: decomposition; ${ }^{\mathrm{b}}$ calculated data.

$$
\begin{aligned}
& \mathrm{CrO}_{2} \mathrm{Cl}_{2}<\mathrm{MoOCl}_{4} \\
& <\mathrm{MoO}_{2} \mathrm{Cl}_{2} \leq \mathrm{WOCj}_{4}<\mathrm{WO}_{2} \mathrm{Cl}_{2}<\left(\mathrm{UO}_{2} \mathrm{Cl}_{2}\right)
\end{aligned}
$$

However, this is not the sequence which is observed for the volatility of macroscopic amounts (see section 2.3).

In order to compare the different oxychlorides with respect to their production and stability, the enthalpies of the substitution ( $\left.\Delta H_{\text {subst }}^{*}\right)$ and oxidation $\left(\Delta H_{\text {oxi }}^{*}\right)$ reactions of the chlorides and oxychlorides with oxygen were analysed. In Fig. $3 \Delta H_{\text {subst }}^{*}$ and $\Delta H_{\text {oxi }}^{*}$, denoted as $\Delta \mathrm{H}_{\mathrm{n}}$ are shown as a function of $\Delta H_{\mathrm{M}(\mathrm{g})}^{\mathrm{a}}[13,18,17$, $14,19]$. The following reactions were considered.

Substitution reactions:

$$
\begin{aligned}
& \mathrm{MCl}_{6(\mathrm{~g})}+\mathrm{O}_{(\mathrm{g})} \leftrightarrow \mathrm{MOCl}_{4(\mathrm{~g})}+2 \mathrm{Cl}_{(\mathrm{g})} \\
& \mathrm{MCl}_{6(\mathrm{~g})}+2 \mathrm{O}_{(\mathrm{g})} \leftrightarrow \mathrm{MO}_{2} \mathrm{Cl}_{2(\mathrm{~g})}+4 \mathrm{Cl}_{(\mathrm{g})} \\
& \mathrm{MOCl}_{4(\mathrm{~g})}+\mathrm{O}_{(\mathrm{g})} \leftrightarrow \mathrm{MO}_{2} \mathrm{Cl}_{2(\mathrm{~g})}+2 \mathrm{Cl}_{(\mathrm{g})}
\end{aligned}
$$

Oxidation reactions:

$$
\begin{aligned}
& \mathrm{MCl}_{5(\mathrm{~g})}+2 \mathrm{O}_{(\mathrm{g})} \leftrightarrow \mathrm{MO}_{2} \mathrm{Cl}_{2(\mathrm{~g})}+3 \mathrm{Cl}_{(\mathrm{g})} \\
& \mathrm{MCl}_{5(\mathrm{~g})}+\mathrm{O}_{(\mathrm{g})} \leftrightarrow \mathrm{MOCl}_{4(\mathrm{~g})}+\mathrm{Cl}_{(\mathrm{g})}
\end{aligned}
$$

$$
\begin{aligned}
& \mathrm{MCl}_{4(\mathrm{~g})}+2 \mathrm{O}_{(\mathrm{g})} \leftrightarrow \mathrm{MO}_{2} \mathrm{Cl}_{2(\mathrm{~g})}+2 \mathrm{Cl}_{(\mathrm{g})} \\
& \mathrm{MCl}_{4(\mathrm{~g})}+\mathrm{O}_{(\mathrm{g})} \leftrightarrow \mathrm{MOCl}_{4(\mathrm{~g})}
\end{aligned}
$$

$\Delta H_{\text {subst }}^{*}$ and $\Delta H_{\text {oxi }}^{*}$ are always exothermic and, with the exception of reaction (5), increasing with $Z$. In group 6 the reason for the different behaviour of reaction (5) is the higher stability of $\mathrm{MOCl}_{4}$. The increasing values for $\Delta H_{\text {subst }}^{*}$ with $\mathrm{Z}$ for the substitution of the hexachlorides with $\mathrm{O}$-atoms (reactions 3 and 4 ) is an indicator for the systematic increase of the binding energy of oxygen within group 6 and thus the reason for an increasing stability of the dioxydichlorides.

As follows from the discussion of $\Delta H_{\text {diss, }}^{0}$ there are also differences in the reactions of uranium chlorides with oxygen, compared to group 6 elements. The high stability of $\mathrm{UCl}_{6}$ hinders the formation of $\mathrm{UO}_{2} \mathrm{Cl}_{2}$ which then only forms at high oxygen partial pressures.

From the analyses of thermochemical data, it follows, that for gaschromatographic experiments compounds of the oxidation state +6 , namely $\mathrm{MoO}_{2} \mathrm{Cl}_{2}$, $\mathrm{WO}_{2} \mathrm{Cl}_{2}$ and $\mathrm{UCl}_{6}$, are particularly well suited due to their high stability. Since the synthesis of the pure 


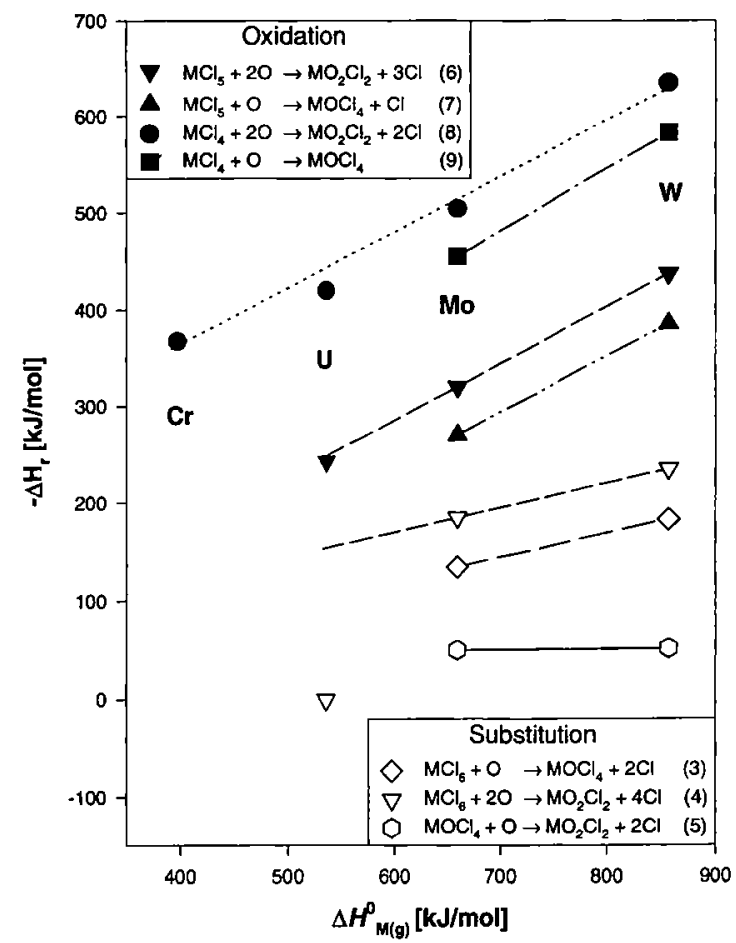

Fig. 3. Enthalpies of substitution $\left(\Delta H_{\text {subsi }}^{*}\right)$ and oxidation reactions $\left(\Delta H_{\mathrm{oxi}}^{*}\right)$ of the chlorides and oxychlorides with atomic oxygen as a function of the standard enthalpy of the gaseous metal $\Delta H_{\mathrm{M}(\mathrm{g})}^{\mathrm{o}}$. From left to right: $\mathrm{M}=\mathrm{Cr}, \mathrm{U}$, Mo and $\mathrm{W}$. Values for substitution reactions have open symbols whereas those for oxidation reactions have filled symbols. The vertical axis $-\Delta H_{r}$ resembles $\Delta H_{\text {subst }}^{*}$ or $\Delta H_{\text {oxi }}^{*}$, depending on the reaction. The tendencies within the group 6 elements are symbolized with lines to guide the eye.

chlorides of group 6 elements requires the elimination of even traces of moisture and oxygen, an experimental condition which is difficult to realize, it appears again appropriate to concentrate on the group 6 oxychlorides.

\subsection{Choice of appropriate gas chemical conditions}

As reactive components for the synthesis of chlorides and oxychlorides in gas adsorption chromatographic experiments $\mathrm{Cl}_{2}, \mathrm{SOCl}_{2}$ and varying concentrations of $\mathrm{O}_{2}$ have been used. When heating $\mathrm{SOCl}_{2}$ over $76^{\circ} \mathrm{C}$ the pyrolysis reaction sets in [30]. We regard as a first step of the pyrolysis reaction:

$$
4 \mathrm{SOCl}_{2(\mathrm{~g})} \rightarrow \mathrm{S}_{2} \mathrm{Cl}_{2(\mathrm{~g})}+2 \mathrm{SO}_{2(\mathrm{~g})}+3 \mathrm{Cl}_{2(\mathrm{~g})}
$$

followed by the reversible reaction:

$$
\mathrm{S}_{2} \mathrm{Cl}_{2(\mathrm{~g})}+2 \mathrm{O}_{2(\mathrm{~g})} \leftrightarrow 2 \mathrm{SO}_{2(\mathrm{~g})}+\mathrm{Cl}_{2(\mathrm{~g})} \text {. }
$$

The partial pressure of $\mathrm{O}_{2}$ is then given by

$$
\mathrm{pO}_{2}=\sqrt{\frac{\mathrm{p}^{2} \mathrm{SO}_{2} \cdot \mathrm{pCl}_{2}}{\mathrm{pS}_{2} \mathrm{Cl}_{2} \cdot \mathrm{K}}}=\sqrt{\frac{12}{\mathrm{~K}}},
$$

with $\mathrm{K}$ being the equilibrium constant of Eq. (11). Some values of $\log \mathrm{K}$ are 100.1, 59.2 and 23.8 at tem- peratures of 298,500 and $1200 \mathrm{~K}$, respectively. The factor 12 results from the partial pressures of $\mathrm{SO}_{2}, \mathrm{Cl}_{2}$ and $\mathrm{S}_{2} \mathrm{Cl}_{2}$ from Eq. (10) inserted into Eq. (11) assuming stoichiometric conditions. It is assumed, that only trace amounts of $\mathrm{O}_{2}$ are present. The oxygen partial pressure calculated in such a manner can be regarded as a lower limit, reached with pyrolysis of $\mathrm{SOCl}_{2}$. Not included in this consideration are the reaction kinetics of the different processes, which are poorly known.

If $\mathrm{O}_{2}$ is added the getter capacity of the system will be reduced, and, with high amounts of oxygen, $\mathrm{SO}_{3}$ is formed and the getter capacity of the system will be exhausted. It is known, however, that the equilibrium of the reaction

$$
\mathrm{SO}_{2}+1 / 2 \mathrm{O}_{2} \leftrightarrow \mathrm{SO}_{3}
$$

is reached only very slowly. In consequence, the addition of $\mathrm{O}_{2}$ will result most likely in a higher partial pressure of oxygen $\left(\mathrm{pO}_{2}\right)$ than estimated from equilibrium conditions. In order to determine the most likely chemical compound synthesized in our experiments with carrier free nuclides, the equilibrium $\mathrm{pO}_{2}$ of the following gas phase reaction were calculated and are shown in Fig. 4.

$$
\begin{aligned}
& \mathrm{MCl}_{6(\mathrm{~g})}+1 / 2 \mathrm{O}_{2(\mathrm{~g})} \leftrightarrow \mathrm{MOCl}_{4(\mathrm{~g})}+\mathrm{Cl}_{2(\mathrm{~g})} \\
& \mathrm{MCl}_{6(\mathrm{~g})}+\mathrm{O}_{2(\mathrm{~g})} \leftrightarrow \mathrm{MO}_{2} \mathrm{Cl}_{2(\mathrm{~g})}+2 \mathrm{Cl}_{2(\mathrm{~g})} \\
& \mathrm{MOCl}_{4(\mathrm{~g})}+1 / 2 \mathrm{O}_{2(\mathrm{~g})} \leftrightarrow \mathrm{MO}_{2} \mathrm{Cl}_{2(\mathrm{~g})}+\mathrm{Cl}_{2(\mathrm{~g})}
\end{aligned}
$$

The equilibrium constants of the reactions were taken from Refs. [13, 17, 18, 19, 14]. For the calculation of $\mathrm{pO}_{2}$ it was assumed, that $\mathrm{pCl}_{2}$ is the sum of $\mathrm{Cl}_{2}$ originating from pyrolysis and of added $\mathrm{Cl}_{2}$. In addition, equal partial pressures of the compounds on the left and right hand side of the equilibrium reaction were assumed (e.g. $\mathrm{pMOCl} / \mathrm{pMCl}_{6}=1$ ).

As shown in Fig. 4, at low $\mathrm{pO}_{2}$ the formation of the pure chlorides or the oxytetrachlorides is likely, whereas at higher $\mathrm{pO}_{2}$, the dioxydichloride is the most probable compound. Even the $\mathrm{pO}_{2}$ from the pyrolysis reaction of $\mathrm{SOCl}_{2}$ (dotted lines) would be sufficient to form $\mathrm{MoOCl}_{4}$ or $\mathrm{WOCl}_{4}$. Already at relatively low $\mathrm{pO}_{2}$ the probability to form $\mathrm{MoO}_{2} \mathrm{Cl}_{2}$ or $\mathrm{WO}_{2} \mathrm{Cl}_{2}$ is very high.

In case of $\mathrm{U}, \mathrm{pO}_{2}$ from the pyrolysis reaction leads to formation of $\mathrm{UCl}_{6}$.

\subsection{Volatility of chlorides and oxychlorides of group 6 elements}

A compilation of the thermodynamic data for (oxy)chlorides of $\mathrm{Mo}, \mathrm{W}$ and $\mathrm{U}$ available from the literature is shown in Table 1, original data as well as compiled values are included. For macroscopic amounts, the vapour pressure of a compound is a measure of its volatility. In Fig. 5, the vapour pressure curves of the gaseous state over the respective solids or liquids for Mo-, W-, and U-chlorides and oxychlorides are 


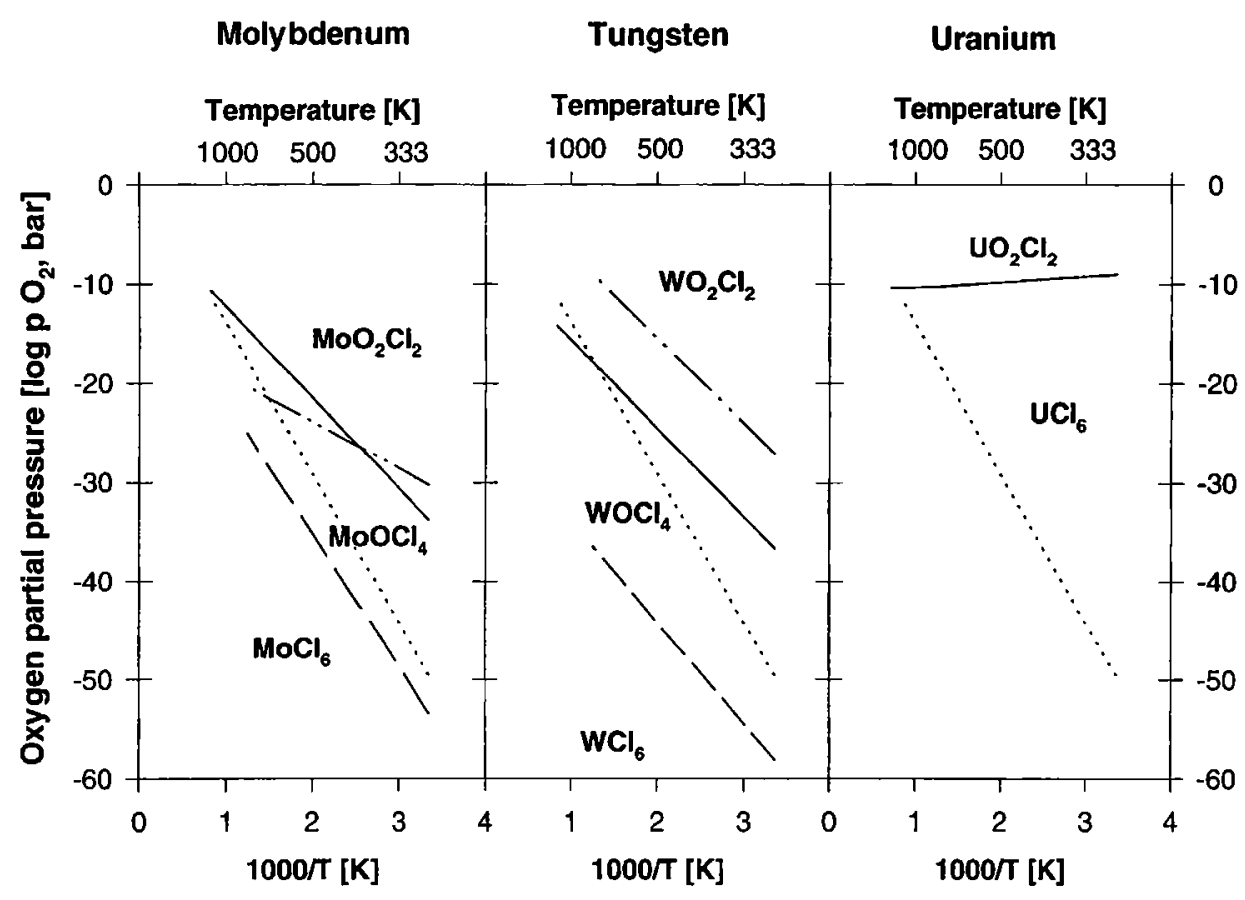

Fig. 4. Oxygen partial pressures as a function of temperature for equilibrium conditions (see text). The dotted lines represent the equilibrium oxygen partial pressures from pyrolysis of thionyl chloride. The solid lines are the equilibrium oxygen pressures of the conversion from a pure chloride to the respective dioxydichloride. The dashed lines represent the equilibrium oxygen pressures of the conversion from a pure chloride to the respective oxytetrachloride. Finally, the dashed-dotted lines represent the equilibrium oxygen pressures of the conversion from a oxytetrachloride to the respective dioxydichloride.

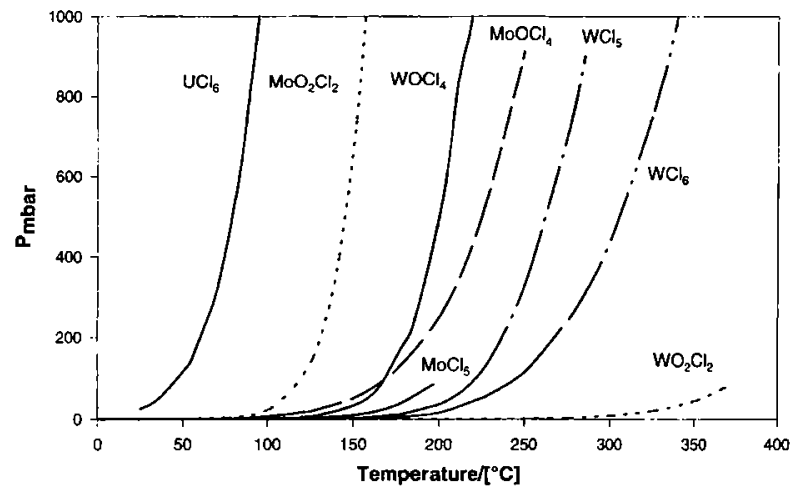

Fig. 5. Vapour pressure curves of the gaseous state over the respective solids or liquids for Mo-, W- and U-chlorides and oxychlorides from Ref. $[13,18]$.

shown. In the system $\mathrm{Mo}-\mathrm{O}-\mathrm{Cl}$ four species are expected to exist in the gas phase $\left(50^{\circ} \mathrm{C} \leq T \leq 450^{\circ} \mathrm{C}\right)$ : $\mathrm{MoCl}_{5}, \mathrm{MoOCl}_{3}, \mathrm{MoOCl}_{4}$ and $\mathrm{MoO}_{2} \mathrm{Cl}_{2}$. Surprisingly, $\mathrm{MoO}_{2} \mathrm{Cl}_{2}$ has a higher vapour pressure at a given temperature compared to $\mathrm{MoOCl}_{4}$, which decomposes slowly to $\mathrm{MoOCl}_{3}$. This is caused by the structure of the respective solids (see $\Delta S_{\text {sub }}^{o}$ in Table 1 ). In the system $\mathrm{W}-\mathrm{O}-\mathrm{Cl}$ the compounds $\mathrm{WCl}_{5}, \mathrm{WCl}_{6}, \mathrm{WO}_{2} \mathrm{Cl}_{2}$, and $\mathrm{WOCl}_{4}$ should exist in gas phase. The existence of $\mathrm{WOCl}_{3}$ in the gas phase is questionable, it decomposes to $\mathrm{WOCl}_{2(s)}$ and $\mathrm{WOCl}_{4(\mathrm{~g})}$ [26]. At temperatures above $600^{\circ} \mathrm{C} \mathrm{WCl}{ }_{6}$ decomposes to $\mathrm{WCl}_{5}, \mathrm{WCl}_{4}$ and $\mathrm{Cl}_{2}$ [15]. In contrast to $\mathrm{MoO}_{2} \mathrm{Cl}_{2}$, which is stable in gas phase, $\mathrm{WO}_{2} \mathrm{Cl}_{2}$ undergoes a complex decomposition above $290^{\circ} \mathrm{C}$ to $\mathrm{WO}_{3}, \mathrm{WOCl}_{4}$ and $\mathrm{WCl}_{6}$ [15].
There are no indications that $\mathrm{WO}_{2} \mathrm{Cl}_{2}$ as a single molecule is not stable in gas phase. Also, $\mathrm{WOCl}_{4}$ is known to decompose to $\mathrm{WO}_{2} \mathrm{Cl}_{2}$ and $\mathrm{WCl}_{6}$ above $210^{\circ} \mathrm{C}$ [15]. In the system $\mathrm{U}-\mathrm{O}-\mathrm{Cl}$ only the pure chlorides $\left(\mathrm{UCl}_{6}\right.$, $\mathrm{UCl}_{5}, \mathrm{UCl}_{4}$ ) are volatile, with $\mathrm{UCl}_{6}$ being the most volatile species. The volatilization of $\mathrm{UO}_{2} \mathrm{Cl}_{2}$ occurs not without simultaneous decomposition [32]. In air the decomposition starts at $460^{\circ} \mathrm{C}$ with loss of $\mathrm{Cl}_{2}$, the final product being $\mathrm{U}_{3} \mathrm{O}_{8}$.

In comparison with the sequence of $\Delta H_{\mathrm{subl}}^{\mathrm{o}}$ (Eq. 2) the sequence in volatility for macroscopic amounts is reversed for $\mathrm{MoO}_{2} \mathrm{Cl}_{2}$ and $\mathrm{MoOCl}_{4}$ :

$$
\begin{aligned}
& \text { vapour pressure (e.g. at } T=175^{\circ} \mathrm{C} \text { ): } \\
& \mathrm{MoO}_{2} \mathrm{Cl}_{2}>\mathrm{WOCl}_{4} \geq \mathrm{MoOCl}_{4}>\mathrm{WO}_{2} \mathrm{Cl}_{2}
\end{aligned}
$$

However, in a carrier-free experiment no solid phases of the compounds under investigation are present. The process of sublimation has to be replaced by a desorption of a single molecule from the adsorbed state on a surface (usually quartz) to the gas phase. It has been demonstrated, that there exists an excellent correlation between the sublimation enthalpy of macroscopic compounds and the enthalpy of adsorption on quartz surfaces for single molecules [31]. For chlorides, the following correlation was found:

$$
\begin{aligned}
-\Delta \mathrm{H}_{\text {ads }}= & (0.655 \pm 0.042) \Delta \mathrm{H}_{\text {subl }} \\
& +(18.0 \pm 8.8)[\mathrm{kJ} / \mathrm{mol}]
\end{aligned}
$$

In Table 1, deduced $\Delta \mathrm{H}_{\text {ads }}$ values are listed, assuming Eq. (17) is valid also for oxychlorides, which has been established experimentally for $\mathrm{NbOCl}_{3}$ [2]. We there- 
fore conclude that in isothermal gas adsorption chromatography on quartz surfaces the retention times for the compounds have the order given by (2) and not by (16).

\section{Experimental}

\subsection{Production of the radionuclides}

${ }^{104} \mathrm{Mo}\left(T_{1 / 2}=1.0 \mathrm{~min}\right)$ was produced from a ${ }^{235} \mathrm{U}$ fission target at the U-1200 cyclotron of the Forschungszentrum Rossendorf. ${ }^{166} \mathrm{~W}\left(T_{1 / 2}=18.8 \mathrm{~s}\right)$ and ${ }^{167} \mathrm{~W}\left(T_{1 / 2}=19.9 \mathrm{~s}\right)$ [33] were formed in the ${ }^{152} \mathrm{Gd}\left({ }^{20} \mathrm{Ne}, \mathrm{xn}\right){ }^{166-169} \mathrm{~W}$ reaction at a beam energy of $153 \mathrm{MeV}$ and a beam intensity of $100-150 \mathrm{pnA}$ at the PSI PHILIPS cyclotron. The target, containing 0.5 $\mathrm{mg} / \mathrm{cm}^{2}$ of ${ }^{152} \mathrm{Gd}$ (enriched: $26 \%$ ), was prepared by electrodeposition on a $15 \mu \mathrm{m} \mathrm{Be}$ foil. ${ }^{229} \mathrm{U}\left(T_{1 / 2}=\right.$ $58 \mathrm{~min}$ ) was produced by bombarding a stack of 15 ${ }^{232} \mathrm{Th}$ targets with $95 \mathrm{MeV} \alpha$-particles (250 pnA) also at the PSI PHILIPS cyclotron. These targets were $100 \mu \mathrm{g} / \mathrm{cm}^{2}{ }^{232} \mathrm{Th}$ evaporated on $20 \mu \mathrm{m} \mathrm{Al} \mathrm{backings.}$

At the same time, manifold by-products such as ${ }^{165} \mathrm{Hf}\left(T_{1 / 2}=76 \mathrm{~s}\right)$ from $a \times n$-reactions could be used to test the quality of the separation technique.

\subsection{Experimental set-up}

The experimental set-up used in this study consisted of five components: first the target chamber, where the nuclear reaction products were collected, second a gasjet system for the transport of reaction products, third the OLGA system, where chemical reactions and chromatographic separations were accomplished, fourth a so-called recluster unit and finally a detector arrangement, where the detection of $\alpha$ - and $\gamma$-spectra was performed $[2,12]$.

In the target chamber, which was located at an accelerator or at a neutron beam line, the reaction products were thermalized in helium and attached to small carbon aerosol particles. Then the particles were continuously transported through a capillary to the OLGA device. There, in a first section of the chromatographic column (reaction oven) the carbon aerosol particles were stopped on a quartz wool plug. At this position, kept at $900-1000^{\circ} \mathrm{C}$, the volatile species were formed by adding different chlorinating gases (e.g. $\mathrm{Cl}_{2}+\mathrm{O}_{2}$ and/or $\mathrm{SOCl}_{2(\mathrm{~g})}$ ). In order to avoid impurities all connections and fittings in contact with the reactive gas were non-metallic. In addition, the chlorinating gas was filtered before entering the reaction oven. Also, prior to the experiment, the quartz columns were pretreated at $900^{\circ} \mathrm{C}$ in a stream of chlorine gas. This cleaning procedure was necessary to achieve reproducible results. The gas conditions of all experiments are summarized in Table 2. After the desired species were synthesized in the reaction oven, the chromatographic process took place in the second, isothermal part of the quartz chromatography column. Behind the chro- matographic column, the species were reattached to new aerosol particles $(\mathrm{KCl}$ or $\mathrm{CsCl})$ in a water-cooled recluster chamber. This permitted a further transport of the separated products to a $\alpha$ - or $\gamma$-counting tape system. The aerosol particles containing the products were deposited on a computer tape. This spot of activity was moved stepwise in front of PIPS detectors for $\alpha$-counting or a HPGe diode for $\gamma$-spectroscopy. The stepping time was adjusted to the half-life of the nuclide to be measured.

Prior to every chemical investigation the gas-jet was directly connected to the tape counting system to get information about the production rates of produced nuclides. Then, the gas-jet was fed into the OLGA system and the reactive gas mixture was added. At every parameter setting (e.g. isothermal temperature of the column, reaction oven temperature, gas flow rate) the product activity on the tape was measured. From the measured count rates, as a function of the isothermal temperature, integral chromatograms were obtained. These curves allowed to determine the retention times of the species in the column using the half-lives of the nuclides as a clock. With a Monte Carlo model [2, 34, 35] adsorption enthalpies $\Delta \mathrm{H}_{\mathrm{ads}}$ of the compounds on the surface of the quartz chromatography colum were deduced.

\section{Results and discussion}

\subsection{Molybdenum}

The measured relative yields (maximum yields arbitrarily set $=100 \%$ ) obtained for ${ }^{104} \mathrm{Mo}$ are shown in Fig. 6. The maximum absolute chemical yield in the chosen $\mathrm{O}_{2} / \mathrm{SOCl}_{2}$ system was only about $20 \%$. This low yield was attributed to the formation of $\mathrm{SO}_{3}$ droplets in the recluster chamber, which significantly interfered with the reclustering process. The declining yields at temperatures above $300^{\circ} \mathrm{C}$ were associated with diffusional losses in the recluster chamber. A fit of the data with the Monte Carlo model yields $\Delta \mathrm{H}_{\mathrm{ads}}=-90 \pm 3 \mathrm{~kJ} / \mathrm{mol}$. Due to the high $\mathrm{pO}_{2}$ (Table 2) the most probable species is $\mathrm{MoO}_{2} \mathrm{Cl}_{2}$ (Fig. 4). This assignment is further supported by comparing the experimentally determined $\Delta \mathrm{H}_{\mathrm{ads}}=-90 \pm 3 \mathrm{~kJ} / \mathrm{mol}$ with the average $\Delta H_{\text {ads }}$ values from Table 1 . The experimentally determined value is closer to $\Delta \mathrm{H}_{\text {ads }}\left(\mathrm{MoO}_{2} \mathrm{Cl}_{2}\right)$ than to $\Delta \mathrm{H}_{\mathrm{ads}}\left(\mathrm{MoOCl}_{4}\right)$.

\subsection{Tungsten}

Fig. 6 shows the relative yields measured in two separate experiments with different gas compositions (Table 2) using the isotopes ${ }^{166} \mathrm{~W}$ and ${ }^{167} \mathrm{~W}$. The main difference was the amount of $\mathrm{O}_{2}$ in the chlorinating gas. In order to avoid the formation of $\mathrm{SO}_{3}$ droplets in the recluster unit, the amount of $\mathrm{O}_{2}$ was reduced in one of the experiments. Still, $\mathrm{O}_{2}$ impurities on the order of $100 \mathrm{ppm}$ were always present in the OLGA system 
Table 2. Initial gas mixtures of the different experiments shown in Fig. 6. Values are for normal temperature and pressure [STP]

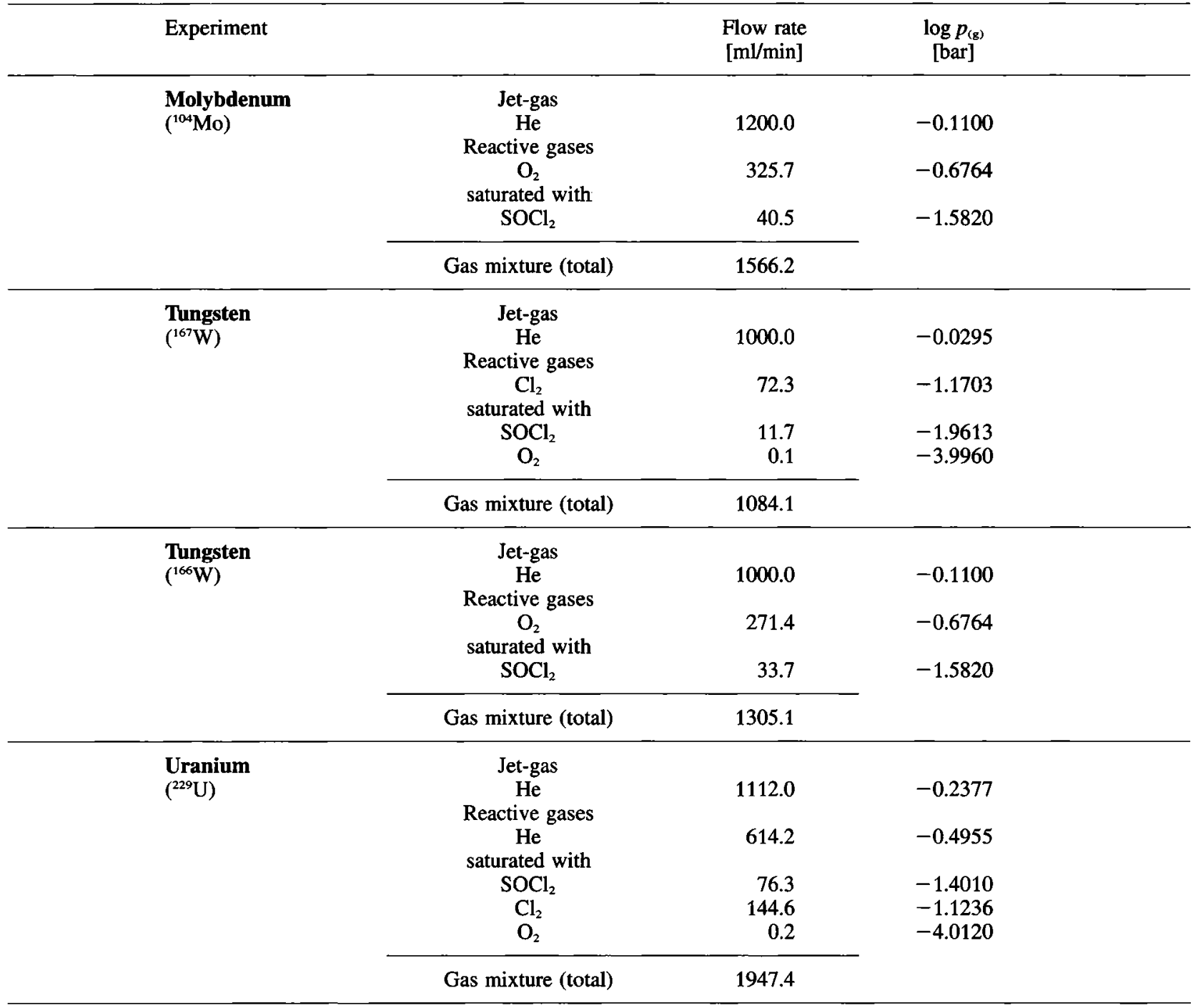

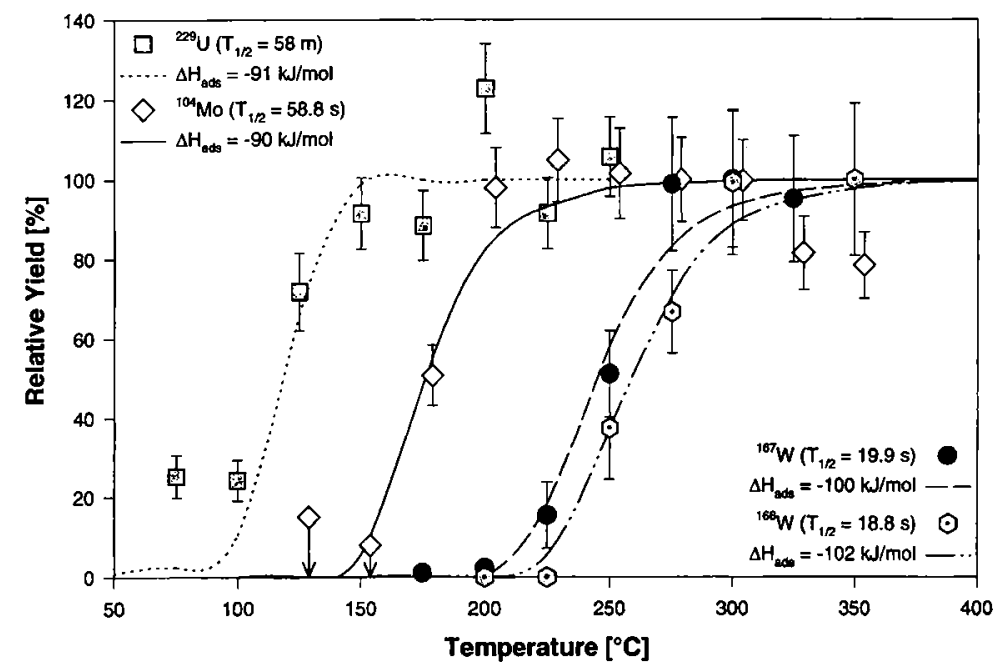

Fig. 6. Measured relative yields of volatile species produced under chlorinating conditions in the OLGA III system with ${ }^{229} \mathrm{U}$, ${ }^{104} \mathrm{Mo}$, ${ }^{166} \mathrm{~W}$ and ${ }^{167} \mathrm{~W}$ as a function of the isothermal temperature: Errors represent statistical uncertainties only $(1 \sigma)$. Symbols with vertical arrows illustrate upper limits. The lines through the experimental data are a best fit calculated with a Monte Carlo model. 


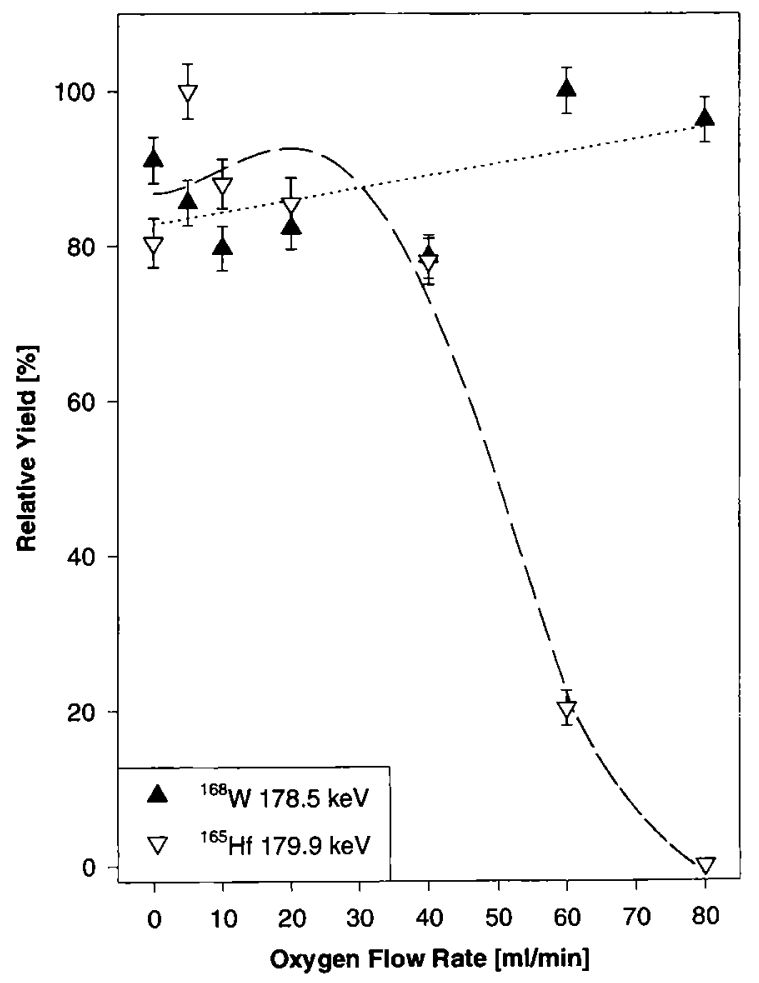

Fig. 7. Relative yields of ${ }^{168} \mathrm{~W}$ and ${ }^{165} \mathrm{Hf}$ as a function of $\mathrm{O}_{2}$ flow rate at constant reactive gas $\mathrm{Cl}_{2} / \mathrm{SOCl}_{2}$ flow rate and isothermal temperature of the column $\left(350^{\circ} \mathrm{C}\right)$.

due to the diffusion of air through the polyethylene capillaries (Table 2). Under these conditions, typical maximum absolute chemical yields for several shortlived isotopes of $\mathrm{W}$ were between 40 and $60 \%$. A fit with the Monte Carlo model yields $\Delta \mathrm{H}_{\text {ads }}=-102 \pm 3$ $\mathrm{kJ} / \mathrm{mol}$ and $-100 \pm 3 \mathrm{~kJ} / \mathrm{mol}$, respectively. Under our chemical conditions, the formation of $\mathrm{WOCl}_{4}$ or $\mathrm{WO}_{2} \mathrm{Cl}_{2}$ is likely (Table 2 and Fig. 4). Since the large variation of $\mathrm{pO}_{2}$ did not change the volatility of the species, formation of $\mathrm{WO}_{2} \mathrm{Cl}_{2}$ is likely. Again, the deduced $\Delta \mathrm{H}_{\text {ads }}$ agree better with the average $\Delta \mathrm{H}_{\text {ads }}\left(\mathrm{WO}_{2} \mathrm{Cl}_{2}\right)$ than with $\Delta \mathrm{H}_{\mathrm{ads}}\left(\mathrm{WOCl}_{4}\right)$ from Table 1 .

In a thermochromatographic study [11] with isotopes of W, using air plus $\mathrm{SOCl}_{2}$ as reactive gas, two deposition peaks were found, which were assigned to $\mathrm{WO}_{2} \mathrm{Cl}_{2}$ at a deposition temperature of $250^{\circ} \mathrm{C}$ and to $\mathrm{WOCl}_{4}$ at $160^{\circ} \mathrm{C}$. It could be shown, that with the short-lived isotope ${ }^{164} \mathrm{~W}\left(T_{1 / 2}=6 \mathrm{~s}\right)$ only the high temperature peak was observed, in agreement with our interpretation of a predominant formation of $\mathrm{WO}_{2} \mathrm{Cl}_{2}$.

Finally, possibilities to separate group 4 from group 6 elements were investigated. First, $\mathrm{O}_{2}$ was added at various concentrations, keeping the isothermal temperature of OLGA fixed at $350^{\circ} \mathrm{C}$. As shown in Fig. 7, the yields of $\mathrm{W}$ remained almost independent of the added $\mathrm{O}_{2}$ gas flow rates, whereas those of $\mathrm{Hf}$ strongly decreased for $\mathrm{O}_{2}$ flow rates $\geq 60 \mathrm{ml} /$ min.

Second, with $\mathrm{Cl}_{2} / \mathrm{SOCl}_{2}$ as reactive gas and a fixed isothermal temperature of $350^{\circ} \mathrm{C}$ the temperature of the reaction oven was varied (Fig. 8). While the yield

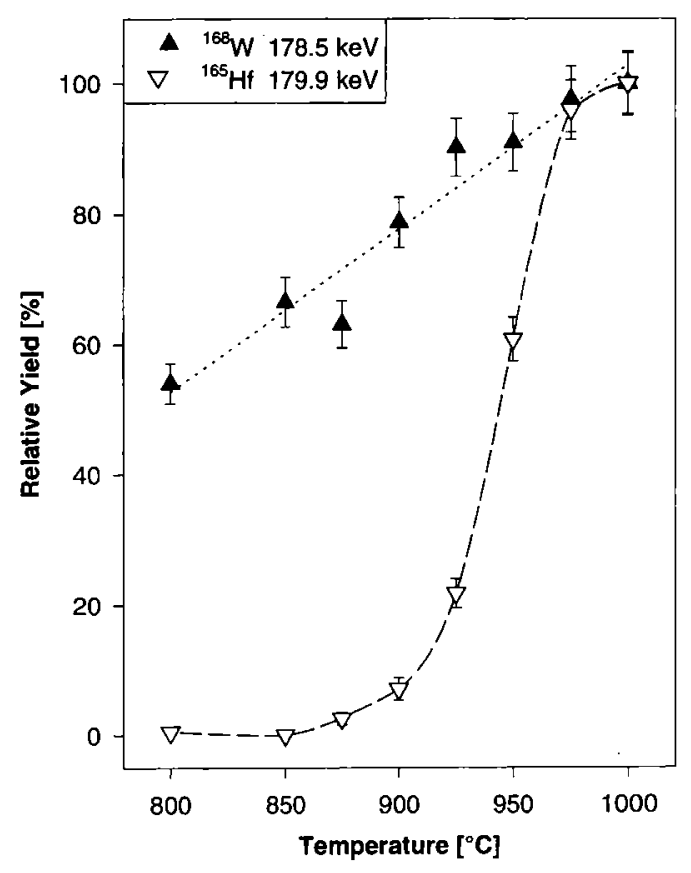

Fig. 8. Relative yields of ${ }^{168} \mathrm{~W}$ and ${ }^{165} \mathrm{Hf}$ as a function of reaction oven temperature with the reactive gas $\mathrm{Cl}_{2} / \mathrm{SOCl}_{2} / \mathrm{O}_{2}$ and a constant isothermal temperature of the column $\left(350^{\circ} \mathrm{C}\right)$.

of $\mathrm{W}$ increased only slightly with temperature that of Hf was essentially zero for temperatures up to $875^{\circ} \mathrm{C}$. One reason for the behaviour of $\mathrm{Hf}$ could be a high retention time due to surface reactions with the quartz wool plug inside the reaction oven.

\subsection{Uranium}

Using the reactive gas $\mathrm{Cl}_{2} / \mathrm{SOCl}_{2}$ (see Table 2), with the isotope ${ }^{229} U\left(T_{1 / 2}=58 \mathrm{~min}\right)$ the relative yield curve shown in Fig. 6 was measured. The fit through the data with the Monte Carlo model results in an adsorption enthalpy of $-91 \pm 3 \mathrm{~kJ} / \mathrm{mol}$. The reason for the different chromatographic curves depicted in Fig. 6 for Mo and $U$ with identical $\Delta H_{\text {ads }}$ values is due to the largely different half-lives of the nuclides ${ }^{104} \mathrm{Mo}$ and ${ }^{229} \mathrm{U}$. Since $\mathrm{UO}_{2} \mathrm{Cl}_{2}$ is expected to have a very high $\Delta \mathrm{H}_{\text {ads }}$ values of $-194.6 \pm 20.1 \mathrm{~kJ} / \mathrm{mol}$ our result strongly supports an assignment of the volatile species to $\mathrm{UCl}_{6}$, even though the discrepancy between experimental and predicted $\Delta \mathrm{H}_{\text {ads }}$ value $(-70.6 \pm 12.2 \mathrm{~kJ} /$ mol, Table 1) is somewhat large.

\section{Summary and conclusion}

From an evaluation of the thermochemical properties of the chlorides and oxychlorides of the group 6 elements Mo and $\mathrm{W}$, as well as of the pseudo-group 6 member $\mathrm{U}$, it was concluded, that for ultra trace amounts of $\mathrm{Mo}$ and $\mathrm{W}$ the dioxydichlorides are the most stable compounds in contrast to $\mathrm{U}$, where it is the hexachloride. 
The OLGA technique was used to study the formation of volatile compounds of short-lived isotopes of the group 6 elements Mo, W and U. Shortlived nuclides of these elements were produced at nuclear facilities and transported to the OLGA device with a $\mathrm{He} / \mathrm{carbon}$ particle gas-jet system. For the formation of volatile compounds the reactive gas mixture $\mathrm{Cl}_{2} / \mathrm{SOCl}_{2}$, containing different partial pressures of $\mathrm{O}_{2}$, was used. For all 3 elements volatile species were observed at isothermal temperatures $\leq 250^{\circ} \mathrm{C}$. From the experimental gas composition, the deduced reaction equilibria for the oxidation of the pure chlorides as a function of temperature, and the deduced $\Delta \mathrm{H}_{\mathrm{ads}}$ values, we conclude that most likely the molecules $\mathrm{MoO}_{2} \mathrm{Cl}_{2}, \mathrm{WO}_{2} \mathrm{Cl}_{2}$ and $\mathrm{UCl}_{6}$ were formed.

These findings provide a basis for the application of the OLGA technique to the study of eka-W, the transactinide element 106 (Seaborgium, Sg).

\section{Acknowledgements}

Some of us (A.T., B.E., D.J., R.D., D.P.) acknowledge the warm hospitality during a beam time at FZ-Rossendorf. Excellent beams delivered by the PHILIPS cyclotron are highly appreciated. This work was supported by the Swiss National Science Foundation.

\section{References}

1. Schädel, M.: Radiochim. Acta 70/71, 207-223 (1996).

2. Türler, A.: Radiochim. Acta 72, 7-17 (1996).

3. Kratz, J. V., Zimmermann, H. P., Scherer, U. W., Schädel, M., Brüchle, W., Gregorich, K. E., Gannett, C. M., Hall, H. L., Henderson, R. A., Lee, D. M., Leyba, D. J., Nurmia, M. J., Hoffman, D. C., Gäggeler, H. W., Jost, D. T., Baltensperger, U., Ya-NaiQi, Türler, A., Lienert, C.: Radiochim. Acta 48, 121-133 (1989).

4. Gäggeler, H. W., Jost, D. T., Kovacs, J., Scherer, U. W., Weber, A., Vermeulen, D., Türler, A., Gregorich, K. E., Henderson, R. A., Czerwinski, K. R., Kadkhodayan, B., Lee, D. M., Nurmia, M., Hoffman, D. C., Kratz, J. V., Gober, M. K., Zimmermann, H. P., Schädel, M., Brüchle, W., Schimpf, E., Zvara, I.: Radiochim. Acta 57, 93-100 (1992).

5. Keller Jr., O. L.: Radiochim. Acta 37, 169-180 (1984).

6. Lazarev, Y. A., Lobanov, Y. V., Oganessian, Y. T., Utyonkov, V. K., Abdullin, F. S., Buklanov, G. V., Gikal, B. N., Iliev, S., Mezentsev, A. N., Polyakov, A. N., Sedykh, I. M., Shirokovsky, I. V., Subbotin, V. G., Sukhov, A. M., Tsyganov, Y. S., Zhuchko, V. E., Lougheed, R. W., Moody, K. J., Wild, J. F., Hulet, E. K., McQuaid, J. H.: Phys. Rev. Lett. 73, 624-627 (1994).

7. Pershina, V., Fricke, B.: J. Phys. Chem. 98, 6468-6473 (1994).

8. Pershina, V., Fricke, B.: J. Phys. Chem. 100, 8748-8751 (1996).
9. Timokhin, S. N., Yakushev, A. B., Perelygin, V. P., Zvara, I.: Chemical Identification of Element 106 by the Thermochromatographic Method, Proceeding of the International School-Seminar on Heavy Ion Physics, Dubna 1, 204 (1993).

10. Timokhin, S. N., Yakushev, A. B., Honggui, XU, Perelygin, V. P., Zvara, I.: J. Radioanal. Nucl. Chem. Lett. 212, 3134 (1996).

11. Yakushev, A. B., Timokhin, S. N., Vedeneev, M. V., Honggui, XU, Zvara, I.: J. Radioanal. Nucl. Chem. 205, 63-67 (1996).

12. Gäggeler, H. W., Jost, D. T., Baltensperger, U., Weber, A., Kovacs, A., Vermeulen, D., Türler, A.: Nucl. Instrum. Methods A309, 201 (1991).

13. Knacke, O., Kubaschewski, O., Hesselmann, K. (Eds.): Thermochemical Properties of Inorganic Substances II, 2nd ed., Springer-Verlag, Berlin (1991).

14. Oppermann, H., Stöver, G.: Z. Anorg. Allg. Chemie 387, 218-229 (1972).

15. Furman, A. A.: Neorganiceskie Khloridy, Izd. Khimiya, Moskva 1980.

16. Samsonov, G. V.: Svoistva elementov, Jzd. Metallurgiya, Moskva 1976.

17. Oppermann, H.: Z. Anorg. Allg. Chem. 379, 262-272 (1970).

18. Oppermann, H.: Z. Anorg. Allg. Chem. 383, 1-13 (1971).

19. Oppermann, H., Stöver, G., Kunze, G.: Z. Anorg. Allg. Chem. 387, 201-217 (1972).

20. Chase jr., M. W., Davis, C. A., Downey jr., J. R., Frurip, D. J., McDonald, R. A., Syverud, A. N.: J. Phys. Chem. Ref. Data 11 (Suppl. 2) (1982).

21. Wagman, D. D., Evans, W. H., Parker, V. B., Schumm, R. H., Halow, I., Bailry, S. M., Churney, K. L., Nuttall, R. L.: J. Phys. Chem. Ref. Data 14 (Suppl. 1) (1985).

22. Schäfer, H., v. Schnering, H.-G., Tillack, J., Kuhnen, F., Wöhrle, H., Baumann, H.: Z. Anorg. Allg. Chem. 353, 281-310 (1967).

23. Shchukarev, S. A., Novikov, G. I., Vasì̀kova, I. V., Suvorov, A. V., Sharupin, N. V., Andreeva, B. N., Baev, A. K.: Zh. Neorg. Khim. 5, 1650-1654 (1960).

24. Novikov, G. I., Galitskii, N. V.: Zh. Neorg. Khim. 10, 576582 (1965)

25. Shchukarev, S. A., Vasilkova, I. V., Sharupin, B. N.: Vestnik Leningrad Uni. 16(22, Ser. Fiz. Khim. 4), 130 (1961).

26. Oppermann, H., Stöver, G., Kunze, G.: Z. Anorg. Allg. Chem. 387, 317-328 (1972).

27. Rand, M. H., Kubaschewski, O.: The Thermochemical Properties of Uranium Compounds, Oliver and Boyd, Edinburgh (1963).

28. Gross, P., Haymann, C., Wilson, G. L.: Monatsh. Chem. 102, 924-927 (1971)

29. Cordfunke, E. H. P., Oweltjes, W., Prins, G.: J. Chem. Thermodyn. 8, 241-250 (1976).

30. Gmelin Handbook of inorganic chemistry: Sulfur, Suppl. Vol. B1 (Thionyl Halides) 8th ed., Frankfurt/Main (1978).

31. Eichler, B., Domanov, V. P., Zvara, I.: Report JINR, Dubna, P12-9454 (1976).

32. Cordfunke, E. H. P., Prins, G., van Vlaanderen, P.: J. Inorg. Nucl. Chem. 39, 2189-2190 (1977).

33. Dressler, R., Fischer, S., Gäggeler, H. W., Buchertseifert, H.: PSI-Report 97-04/I + II (1997).

34. Zvara, I.: Radiochim. Acta 38, 95-101 (1985).

35. Zvara, I.: Isotopenpraxis 26, 251-258 (1990). 